\title{
Canadian First Nations Women Preservice Teachers' Experiences and Perceptions Regarding Technology
}

FRAN LUTHER

\author{
University of Colorado@Denver, \\ Denver, Colorado 80217-3364 \\ fran luther@ceo.cudenver.edu
}

\begin{abstract}
The primary purpose of this research was to collect data for Canadian First Nations educators and policy makers to use in making decisions surrounding issues of First Nations women and technology education. Nine First Nations women preservice teachers at the intern stage of their Indian Teacher Education Program at the University of Saskatchewan were engaged in indepth interviews conceming their experiences and perceptions regarding technology.
\end{abstract}

The study found that the participants defined technology first and foremost as computer-related. Some viewed technology from the cultural aspect, and thought technology used for financial gain would take away from traditional family values. The participants thought that women needed technology training and that they needed to develop self-confidence and become role models in order for First Nations women to exercise leadership in the field of technology.

The participants stated that their university experience was responsible for most of their learning about technology. They did not, however, feel prepared to face the technology they would encounter in schools.

Intimidation, stereotypes, the lack of access and exposure to technology, the lack of a good self-image, lack of time, and lack of role models were perceived to be some of the biggest barriers to First Nations women learning about and using technology. Men in their use of intimidation and stories with negative images of women and technology were perceived as one of the strongest deterrents to First Nations women advancing in the area of technology.

Findings from this study had significant implications. First Nations teacher preparation programs should include required credit courses and establish daycare centers. Band controlled schools should update computers and make provisions for technology education by providing for such courses. Further research such as a collection of stories embracing positive images of First Nations women involved in technological pursuits should be undertaken to help ameliorate the status of First Nations women in technology. 


\section{THE PROBLEM}

\section{$\underline{\text { Rationale }}$}

One of the main concerns of the 1972 Canadian First Nations position paper, Indian Control of Indian Education was to enhance First Nations students' self-identity through the use of relevant resources. Much writing has been done over the past two decades on the use of culturally relevant resources with First Nations students (McEachern \& Luther, 1989; Archibald, 1995). The recent technological advancemens in educational resources, however, has made it necessary for First Nations students to become technologically literate in order to access information resources available for use in schools. American Association of School Librarians (AASL) (1998) advocates the use of technology in school library media centers as a primary tool that allows a connection to be forged between the school library media program and the learning community. These "Technological links to community resources, including public and university libraries, government and other public agencies, and museums, now provide all students with access to previously restricted resources and artifacts" (AASL, 1998, p.129). The need for advancement in the field of technology education in order to access otherwise restricted information is especially important for minority women, such as First Nations women, who are under-represented in the field (Liedtke, 1995).

\section{Canada \& Brusca (1991) contended that:}

If the gender of the user and the possibility that males and females build different mental models are ignored, there is a very real possibility that the next generation of human-machine communication systems will serve to widen than close the technological gender gap. (p.49).

Some research has been conducted which sheds some light on issues related to women and educational technology as well as minorities and educational technology. The absence of research about First Nations women and technology, however, is evident.

Multicultural gender issues need to be addressed in research, for as Susan Metz, Vice President of Women in Engineering Program Administration and Network points out in a recent interview, minority women do encounter a "double whammy" in education. Metz (1995) adds:

While programs are being developed to help minority women pursue degrees and careers in the sciences, faculty directors often assume that minorities are a monolith. What works with one group is not always valid with another. There might be similarities, and there might be issues that are very distinct and separate (Luhrs, 1995, p.14).

Conducting "group-specific" research involving First Nations women and technology, therefore, is warranted. As Battiste (1992) states, "Understanding another way of knowledge can only be perceived from within their own way of knowing" (p.4).

Taylor, Cargo and McAlpine (1993) contend that "Another issue for Aboriginal teacher education programs is how to prepare trainees to be agents of societal and educational change" (p.34). Furthermore, Haig-Brown (1988) insists that a study, 
...can provide data which will help educators remove as predictors of academic achievement such variables as sex, ethnicity, race, language and social class. In short, it can help provide knowledge necessary to achieve the goal of 'equity education'. (p.99).

This study involving Indian Teacher Education Program preservice teachers has been designed to provide such knowledge.

\section{$\underline{\text { Statement of Purpose }}$}

The primary purpose if this research is to collect data which will provide a collective mirror (Blackler, 1992) for First Nations educators and policy makers to use I decision making surrounding issues of First Nations women and educational technology. In essence, "...helping those working within it [the educational system] to recognize and debate their situation and articulate an alternative way of working" (Blackler, 1992, p. 291). This study is an attempt to create "...a space where it is possible to consider approaches to creative and transformist praxis" (Turner, 1992, p.63), providing a service for the people (Klein, 1983). It is not intended that this study in any way fosters or extends what (Battiste, 1992) refers to as "cognitive imperialism". Neither has it attempted to impose a deconstructionist methodology. It is realized, however, that some forms of deconstruction may occur to the assumed stability and order (Calas \& Smircich, 1992) as the women choose to effect social change surrounding the issues involved in this study.

\section{$\underline{\text { Research Questions }}$}

This study was designed to investigate the following questions that were based on questions posed by Trautman, Hayden and Smink (1995):

- What are some of the perceived barriers to change in the advancement of First Nations women in the field of technology?

- What are some of the perceived facilitators to change in the advancement of First Nations women in the field of technology?

- What action needs to be taken to empower First Nations women in the field of technology?

- What do First Nations women need to exercise leadership in the field of technology?

\section{Definitions of Terms}

Several terms used in this study require clarification. The following provides operational definitions for these terms:

First Nations. Canadian Aboriginal people have chosen this term to describe themselves. The term has political connotations that are especially meaningful in negotiations with the Canadian Federal Government. The premise in adopting this title is that in treaty negotiation, it can be asserted that treaties are only made between Nations. Aboriginal people were the first nations in Canada and deserve their rightful considerations. The plurality of the term denotes the diversity of the people it represents. 
Band-Contolled: In trying to shed an educational milieu that promotes cultural imperialism, many First Nations bands have established their own school(s). The decisionmaking for each school rests with the local people through educational councils rather than being dictated by the federal government as was done in the past.

\section{Significance of the Research}

While this culturally-specific research may inform band-controlled schools and First Nations teacher education programs, the research also may be useful to provincial educational institutions. This study may offer information which may help them "...to understand and incorporate alternative realities" (Gregen, 1992, p.223). For as Gergen (1992) states:

We must inquire not only into the kinds of cultural patterns served or discredited by given theoretical positions, but also into the potential for theories to offer new alternatives and options to the culture (both organizational and otherwise). (p.218).

Post-secondary teacher education that has a strong technology component, therefore, may learn ways to attract minority women and address relevant leadership issues in technology education.

\section{Delimitations}

This study contains certain delimitations. They are as follows:

Exclusively, First Nations preservice women teachers enrolled in the Indian Teacher Education Program (ITEP) at the University of Saskatchewan were asked to participate. These women possessed common experiences in having come through the Indian Teacher Education Program, but their backgrounds differ in their tribal affiliations and geographical experiences. The investigation was restricted to the preservice teachers' perceptions and experiences regarding technology. The interviews were conducted solely during the pre-internship preservice period of the participant's programs. The site was confined to the Indian Teacher Education program at the University of Saskatchewan.

\section{METHODOLOGY}

\section{Setting for the Investigation}

In order to access First Nations preservice women teachers, the Indian Teacher Education Program (ITEP) at the University of Saskatchewan was chosen as the setting for this study. ITEP was established in 1973 at the request of the First Nations people of Saskatchewan. ITEP students receive a Bachelor of Education degree from the University of Saskatchewan upon successful completion of the four year program.

\section{$\underline{\text { Participants }}$}

First Nations preservice women teachers were asked to participate in this study. The women selected were individuals at the pre-intern stage of their program. The participants met the following criteria: 
1. they were enrolled in the Indian Teacher Education Program at the University of Saskatchewan

2. they were at the pre-intern stage of their educational program.

In total there were one hundred and ninety Indian Teacher Education Program students. Twenty of these were at the pre-internship stage. Fourteen of the pre-interns were women, six were men.

The preservice stage of teachers, in which the ITEP students go into schools to gain practical experience as part of their teacher preparation program, was chosen in order to help ameliorate the present status of minority women and technology. As the Status of Women Canada (1989) recommends:

...The pre-service training and ongoing professional development of educators and counselors at all levels incorporate an understanding of the consequences of the underrepresentation of girls and women in math, science and technology as well as methods to promote the participation of girls and women in these fields of study...(p.ii).

Sardo-Brown (1995) contends that we need to take measures to ensure that educators do not continue to teach in the non-gender equitable way they were taught. She states that, "Teacher educators should address gender-bias issues among preservice education majors so that the same patterns do not continue" (Sardo-Brown, 1995, p.22).

\section{$\underline{\text { Data Collection }}$}

A conversational style of interviewing (Oakley, 1982) was employed. Open ended questions based on the above research questions were used. A copy of the interview questions lay on the table. Some participants who identified themselves as English-as-aSecond-Language speakers asked to read the questions from the sheet on the table, for comprehension purposes. The interviews were recorded onto audiotape. At the end of the interview, a First Nations' protocol of giving gifts in exchange for a sharing of knowledge and wisdom was followed. Usually this protocol is in the form of giving gifts of tobacco to elders (Colorado, 1985).

\section{Data Treatment}

The oral data from the interviews were transcribed. Data were reported on perceived barriers and facilitators to change in the advancement of First Nations women in the field of technology, perceived actions to be taken to advance women in the field of technology, and what was perceived to be needed for First Nations women to exercise leadership in the field of technology. Other taxonomies imposed by the participants were recognized. For the purposes of this paper, the issue of access has been addressed.

\section{$\underline{\text { Recommendations for Indian Teacher Education Programs }}$}

A number of recommendations for First Nations teacher education programs can be drawn from the findings of this study. Several recommendations for First Nations teacher education programs were directly related to the culturally-defined role of principal child 
care-giver posed a barrier of time to their succeeding in the field of technology. These recommendations are as follows:

Credited computer courses should be added to preparation programs. Since time was cited as a barrier to First Nations women learning about and using technology, a computer course with credits would mean that the preservice teachers would not need to spend extra time learning computer skills.

Course loads should be reduced in order for students to include additional computer coursework. Simply adding a computer class as listed above would not necessarily provide access for the preservice teachers if they already have a full slate of required classes. If the course load is not reduced when a required computer course is added, once again, time would create too formidable a barrier to the women.

Relevant institutions should ensure that university computer classes fall within students' schedules. As a remedy to the barrier of time, the participants suggested that computer classes offered should not require the preservice teachers to make an extra trip to campus not require them to arrange for additional childcare. A computer class offered during the regular scheduled time period of classes would facilitate access for women into technological education. Daycare centers were recommended by the participants for both single and married mothers in educational as well as work situations. In order to help alleviate the time constraint caused by childcare as mentioned in the above discussion on culturally-related issues, First Nations preservice women teachers need childcare support such as daycare centers.

It also was recommended that a computer class should be required in the preservice teachers' program. As one participant stated:

Maybe if they understood that it could benefit them. [That] it could benefit them in their community...or their children. Then maybe they would want to start learning about technology.

By facilitating this, programs would emphasize the importance of technological education to preservice teachers.

Another recommendation was that technology should be integrated into other university classes. The participants felt that a quick introduction to a specific form of technology was not adequate to have the preservice teachers become proficient in the use of that technology. The integration aspect also would allow preservice teachers an opportunity for application of the technology in their educational experience.

The aspect of integrating technology into other courses becomes especially important when one realizes that the library online catalog, which was the only technology everyone in Question B4, said they had experiences, was introduced to the students through a librarian from the University giving a workshop which was integrated into other classes the students were taking. This type of integration of technological education would therefore seem to be the most effective was to have students learn about, and gain first hand experience with, technology. 
Recommendations for Band-Controlled Schools

In addressing the issues of access as discussed above, the participants in the study recommended that band-controlled schools should facilitate computer use by the students. One way for First Nations women to become proficient users of technology, is for them to learn it as children. The participants felt that having access and exposure to computers would help provide self-confidence for the students in the field of technology.

\section{$\underline{\text { Recommendations for Politicians }}$}

In clarifying the issue of access, the major recommendation for politicians, inherent in the participants' comments, focused on the politicians placing technology education higher on their agendas. First, the First Nations women in the study recommended that politicians ensure funding for computer courses. The women felt that sometimes technology training is not given a high priority for resource allocation by politicians. Sometimes technology training for preservice teachers is considered as personal gain rather than seen as beneficial to the students these women will teach. Single women who are students may not be able to afford to enroll in additional courses because of the lack of funding. Second, it was recommended that politicians initiate on-reserve technology training so that women are not required to leave the reserve for technology training nor for a better technology-related job.

\section{CONCLUSION}

This study is unique, not only in its original contribution to knowledge, but also in its bringing together issues related to access to technology and the challenges this issue brings to women. The discussion of access to technology issues in this study is further influenced by the consideration of cultural minorities. It is hoped that the recommendations to teachereducation programs, band-controlled schools and to politicians may advance the access of technology to minority women and therefore aide in their use of technology as a primary tool in accessing information in school libraries.

\section{REFERENCES}

American Association of School Librarians \& Association for Educational Communications and Technology. (1998). Information power: Building partnerships for learning. Chicago: American Library Association.

Archibald, J. (1995). Locally developed Native studies curriculum: An historical and philosophical rationale. In M. Battiste \& J. Barman (Eds.), First Nations education in Canada: The circle unfolds, (pp. 73-98). Vancouver: UBC Press.

Battiste, M. (1992). Indigenous epistemology in modern thought and education. An occasional paper of the Mikmaq Research Center, Mikmaq College Board at University College of Cape Breton.

Blackler, F. (1992). Formative contexts and activity systems: Postmodern approaches to the management of change. In M. Reed \& M. Hughes (Eds.). Rethinking organization: New directions in organization theory and analysis (pp. 273-294). Newbury Park, CA: Sage.

Canada, K., \& Brusca, F. (1991). The technological gender gap: Evidence and recommendations for educators and computer-based instruction designers. Educational Technology Research and Development, 39 (2), 43-51. 
Calas, M. B., \& Smircich, L. (1992). Re-writing gender into organizational theorizing: Directions for feminist perspectives. In M. Reed \& M. Hughes (Eds.). Rethinking organization: New directions in organization theory and analysis (pp. 227-253). Newbury Park, CA: Sage.

Colorado, P. (1988). Bridging Native and western science. Convergence, 21, 49-68.

Gergen, K. J. (1992). Organization theory in the postmodern era. In M. Reed \& M. Hughes (Eds.). Rethinking organization: New directions in organization theory and analysis (pp. 207-226). Newbury Park, CA: Sage.

Klein, R. D. (1982). How to do what we want to do: Thoughts about feminist methodology. In G. Bowles \& R. D. Klein (Eds.), Theories of women studies, (pp. 88-104). London: Routledge \& Kegan Paul.

Liedke, J. A. Changing organizational culture of technology education to attract minorities and women. The Technology Teacher, 9-14.

Luhrs, J. (1995). Closing the gender gap. The Hispanic Outlook in Higher Education, 5 (20), 13-25.

McEachern, W., \& Luther, F. (1989). The relationship between culturally relevant reading materials and listening comprehension of Canadian Native Indian Children. Language, Culture and Curriculum, 2 (1), 55-60.

Oakley, A. (1981). Interviewing women: A contradiction in terms. In H. Roberts (Ed.), Doing feminist research, (pp.30-61). London: Routledge \& Kegan.

Sardo-Brown, D. (1995). Preservice education majors' perceptions of gender bias in their own schooling. The Delta Kappa Gamma Bulletin, 61 (4), 21-28.

Status of Women Canada and Manitoba Women's Directorate. (1989). Participation of girls and women in math, science and technology. [Ottawa].

Taylor, D. M., Cargo, M. B., \& McAlpine, L. (1993). Education in Aboriginal communities: Dilemmas around empowerment. Canadian Journal of Native Education, 20 (1), 34-39.

Trautman, D. K., Hayden, T. E., \& Smink, J.M. (1995). Women surviving in technology education: What does it take? The Technology Teacher, 39-42.

Turner, B. A. (1992). The symbolic understanding of organizations. In M. Reed \& M. Hughes (Eds.). Rethinking organization: New directions in organization theory and analysis (pp. 46-66). Newbury Park, CA: Sage. 